\title{
Serotaxonomical Analyses of Some Streptomyces and Related Organisms
}

\author{
By MALIN RIDELL ${ }^{1}$ AND S. T. WILLIAMS ${ }^{2 *}$ \\ ${ }^{1}$ Department of Medical Microbiology, University of Göteborg, S-413 46 Göteborg, Sweden \\ ${ }^{2}$ Department of Botany, University of Liverpool, Liverpool L69 3BX, U.K.
}

(Received 28 February 1983; revised 30 March 1983)

\begin{abstract}
Fifteen strains of Streptomyces, two of Streptoverticillium and one of 'Nocardia' mediterranea were studied by the immunodiffusion technique and the results were compared with those of a previous phenetic study. Both the serological and phenetic analyses demonstrated that 'Nocardia' mediterranea was different from strains of Streptomyces and Streptoverticillium. The latter two genera were phenetically distinguishable but demonstrated a comparatively close serological relationship. Those strains of Streptomyces and Streptoverticillium which shared a high number of precipitinogens also belonged to the same phenetic cluster, while strains which were less serologically related usually fell into different clusters. Thus there was good evidence of a general congruence between serological and phenetic similarity. The immunological results also supported the phenetic evidence in suggesting that many species in the genus Streptomyces should be combined. Similar evidence was obtained for the genus Streptoverticillium.
\end{abstract}

\section{INTRODUCTION}

Immunology has aided the taxonomy of several actinomycete genera, including Actinomyces (Holmberg et al., 1975; Bowden et al., 1976), Mycobacterium, Nocardia and Rhodococcus (Ridell \& Norlin, 1973; Ridell, 1974, 1975, 1981a, b, 1983), Micropolyspora (Arden Jones et al., 1979) and Frankia (Baker et al., 1981).

The application of immunodiffusion techniques to streptomycetes by Cross \& Spooner (1963) demonstrated that serology was of potential taxonomic value in this genus. However, there have been few meaningful serotaxonomic studies subsequently. The results of Kwapinski (1970, 1972) provided a complex pattern of cross-reactions which were of little taxonomic value; the serology of streptomycetes associated with potato scab showed little correlation with their pathogenicity (Bowman \& Weinhold, 1963; Vruggink \& Maat, 1968).

The serological study of actinomycetes has often been confused by poor selection of strains (Lacey et al., 1978), accentuated by lack of objective classification schemes. Such problems have been particularly marked in the genus Streptomyces. However, a recent numerical classification of most of the described species of Streptomyces and related genera (Williams et al., 1983) indicated that the number of species could be drastically reduced. It was therefore decided to determine the serological relationships of strains representing some of the major clusters defined by Williams et al. (1983) in order to evaluate the integrity of the phenetic groups and the potential of serology in the taxonomy of streptomycetes.

\section{METHODS}

Test strains. Fifteen strains of Streptomyces, two of Streptoverticillium and one of 'Nocardia' mediterranea were studied (Table 1). These represented eleven of the major clusters defined by Williams et al. (1983).

Antigen preparation. Strains were inoculated into flasks of glucose $(1 \%, w / v)$-nutrient broth (Difco) which were incubated on a rotary shaker at $33^{\circ} \mathrm{C}$. When good growth was obtained, the cells were harvested by filtration, washed three times in $0.01 \mathrm{M}$-phosphate buffer $(\mathrm{pH} \mathrm{7.2)}$ and disintegrated with an X-press apparatus (Edebo, 
1960). Cell debris were sedimented by centrifugation ( $23500 \mathrm{~g}$ for $15 \mathrm{~min}$ ) and the supernatant extract was diluted in phosphate buffer to give a concentration corresponding to $140 \mathrm{mg} \mathrm{semi-dry} \mathrm{bacterial} \mathrm{mass} \mathrm{ml}^{-1}$. The extracts were then sterilized by filtration.

Antisera preparation. The strains Streptomyces griseus ISP 5236, S. diastaticus ISP 5496, S. goshikiensis ISP 5190 and Streptoverticillium cinnamoneum ISP 5005 were used for antisera production. These represented the major phenetic clusters 1, 19,61 and 55, respectively. Rabbits were injected intracutaneously at eight different dorsal sites, with reinjections 21 and $35 \mathrm{~d}$ after the initial one. If necessary, additional injections at $14 \mathrm{~d}$ intervals were given until a sufficient antibody response was obtained. The suspension used for the initial injections consisted of $2 \mathrm{ml}$ Freund's adjuvant containing $1 \mathrm{ml}$ antigen preparation, $0.9 \mathrm{ml}$ liquid paraffin wax, $0.1 \mathrm{ml}$ Arlacel A and $20 \mathrm{mg}$ cells of the homologous organism, killed by autoclaving for $15 \mathrm{~min}$, dried and ground in a mortar. The injections on day 21 contained $1 \mathrm{ml}$ Freund's adjuvant. The injections on day 35 and any subsequent ones, consisted of $0.5 \mathrm{ml}$ antigen preparation and $0.5 \mathrm{ml} 0.01 \mathrm{M}$-phosphate buffer $(\mathrm{pH} \mathrm{7.2)} \mathrm{but} \mathrm{no} \mathrm{adjuvant.} \mathrm{The} \mathrm{rabbits}$ were bled for control immediately before the first injection and, in order to evaluate the antibody response, one week after each injection. The final bleeding took place two weeks after the last injection.

Immunodiffusion technique. The analyses were carried out using a microplate modification (Wadsworth, 1962) of the immunodiffusion technique of Ouchterlony $(1958,1962)$.

Reference precipitation systems. Four systems were utilized, one for each of the strains selected for antiserum production. The principles for the establishment and use of serological reference systems have been described previously (Ridell, 1975; Baker et al., 1979). Only the precipitinogens which could be identified by the reference systems were used in the comparison with the phenetic data. However, the occurrence of unidentified precipitinogens was also noted.

\section{RESULTS}

The numbers of precipitates identified for the reference systems were 10 for Streptomyces griseus, 9 for $S$. goshikiensis, and 8 each for $S$. diastaticus and Streptoverticillium cinnamoneum. The numbers of precipitinogens shared by each reference and test strain, together with their phenetic similarities (Williams et al., 1983) are given in Table 1. The unidentified precipitates, ranging from one to three, which occurred in most of the test combinations, are not included in these data. Most test strains shared at least one identifiable precipitinogen with the four reference strains. The notable exception was 'Nocardia' mediterranea, which did not form identifiable precipitates with any of the reference sera. Two unidentified precipitates were, however, detected when this strain was analysed by the $S$. griseus system. Likewise, no identifiable precipitates were detected in the $S t$. griseocarneum-S. diastaticus test-combination, but here also some unidentified precipitates occurred.

The $S$. griseus reference strain had the highest number of precipitinogens (6 or 7) in common with strains of its own phenetic sub-cluster (1B). It also had a moderate number of precipitinogens in common with strains from other clusters $(1 \mathrm{C}, 5,10,12)$ with which it shared a similarity of over $74 \%$. However, $S$. coelicolor (sub-cluster 1 A) which shared a phenetic similarity with $S$. griseus of $79.2 \%$, produced only two precipitinogens.

Although the $S$. diastaticus reference strain shared two or three precipitinogens with most streptomycetes, it was not closely related serologically to any of the test strains. Streptomyces diastaticus was the sole representative of cluster 19 and therefore generally had a fairly low phenetic similarity to the other test strains. The phenetic similarity between $S$.diastaticus and $S$. olivaceus was $79 \cdot 2 \%$, but these organisms had only three precipitinogens in common.

The $S$. goshikiensis reference strain shared six precipitinogens with $S$. lavendulae, the other representative of cluster 61 . Otherwise it showed relatively few reactions, reflecting its generally low phenetic similarity to the other test strains.

A similar pattern was given by the Streptoverticillium cinnamoneum reference system. This strain shared five precipitinogens with Stv. griseocarneum, which was placed into the same phenetic cluster, but shared only one, two or three antigens with the other strains tested.

A summary of the relationships between the phenetic and the serological similarities is given in Table 2. 
Table 1. Number of precipitinogens identified by comparative immunodiffusion analysis using four reference systems

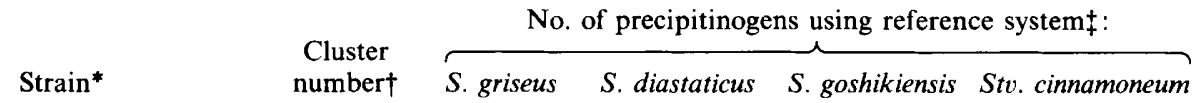

Streptomyces griseus ISP $5236 \S$

S. griseinus ISP 5047

$S$. griseobrunneus ISP 5066

S. globisporus ISP 5199

S. coelicolor ISP 5233

S. olivaceus ISP 5072

S. exfoliatus ISP 5060

S. fulvissimus ISP 5593

$S$. rochei ISP 5231

S. albus ISP 5313

$S$. diastaticus ISP $5496 \S$

$S$. griseoruber ISP 5281

$S$. platensis ISP 5041

S. lavendulae ISP 5069

S. goshikiensis ISP $5190 \S$

Streptoverticillium

cinnamoneum ISP $5005 \S$

Stv. griseocarneum ISP 5004

'Nocardia' mediterranea

ATCC 13685

$1 \mathrm{~B}$
$1 \mathrm{~B}$
$1 \mathrm{~B}$
$1 \mathrm{~B}$
$1 \mathrm{~A}$
$1 \mathrm{C}$
5
10
12
16
19
21
29
61
61
55
55
53

$\begin{aligned} 10 \|(100) & 3(70 \cdot 6) \\ 7(81 \cdot 3) & 2(70 \cdot 6) \\ 6(81 \cdot 3) & 3(72 \cdot 0) \\ 7(87 \cdot 8) & 3(65 \cdot 5) \\ 2(79 \cdot 2) & 3(74 \cdot 2) \\ 3(75 \cdot 6) & 3(79 \cdot 2) \\ 4(74 \cdot 9) & 3(77 \cdot 0) \\ 4(75 \cdot 6) & 2(70 \cdot 6) \\ 4(74 \cdot 2) & 3(70 \cdot 6) \\ 2(69 \cdot 1) & 2(69 \cdot 8) \\ 2(70 \cdot 6) & 8 \|(100) \\ 2(62 \cdot 6) & 2(77 \cdot 7) \\ 2(63 \cdot 4) & 2(68 \cdot 4) \\ 2(65 \cdot 5) & 2(60 \cdot 5) \\ 1(72 \cdot 7) & 1(69 \cdot 1) \\ & \\ 2(66 \cdot 2) & 1(67 \cdot 0) \\ 2(73 \cdot 4) & 0(62 \cdot 6) \\ & \\ 0(69 \cdot 1) & 0(69 \cdot 8)\end{aligned}$

$2(72 \cdot 7)$

$2(72 \cdot 7)$

$3(69 \cdot 8)$

$2(69 \cdot 1)$

$2(67 \cdot 7)$

$3(68 \cdot 4)$

$2(70 \cdot 6)$

$2(68.4)$

$2(72 \cdot 7)$

$1(66 \cdot 2)$

$1(69 \cdot 1)$

2 (64.1)

2 (69.1)

6 (79.9)

9||$(100)$

$2(77 \cdot 7)$

$2(76 \cdot 3)$

$0(66 \cdot 2)$

$3(66 \cdot 2)$

$1(61 \cdot 9)$

$1(64 \cdot 8)$

$2(62 \cdot 6)$

2 (68.4)

$2(66 \cdot 2)$

$1(71 \cdot 3)$

$1(70 \cdot 6)$

$3(70 \cdot 6)$

$2(68.4)$

$1(67.0)$

1 (61.9)

$3(78 \cdot 5)$

$1(72 \cdot 0)$

$2(77.7)$

$8 \|(100)$

5 (79.9)

$0(65 \cdot 5)$

* Sources: ISP, International Streptomyces Project; ATCC, American Type Culture Collection, Rockville, Md., U.S.A.

$\dagger$ Allocation to clusters defined at the $77.5 \% S_{S M}$ similarity level from Williams et al. (1983). Sub-clusters $1 \mathrm{~A}, 1 \mathrm{~B}$ and $1 \mathrm{C}$ were defined at the $81 \% S_{S M}$ similarity level.

$\ddagger$ The numbers in parentheses are $S_{S M}$ similarity values from Williams et al. (1983).

$\S$ Reference strain.

I) Total number of identifiable precipitates in the reference system.

Table 2. Comparison between the phenetic similarities of reference strains and test strains and the number of precipitinogens shared

Mean no. of precipitinogens shared with reference strain*:

$S_{S M}$ value of
test strain
$(\%)$
$>75$
$70-74 \cdot 9$
$65-69 \cdot 9$
$<65$

$\begin{array}{cccc}\begin{array}{c}\text { S. griseus } \\ \text { ISP 5236 }\end{array} & \begin{array}{c}\text { S. diastaticus } \\ \text { ISP 5496 }\end{array} & \begin{array}{c}\text { S. goshikiensis } \\ \text { ISP 5190 }\end{array} & \begin{array}{c}\text { Stv. cinnamoneum } \\ \text { ISP 5005 }\end{array} \\ 5.6 & (8) & (9) & (8) \\ 2.6 & 4.0 & 4.8 & 4.5 \\ 1.5 & 2.7 & 2.0 & 1.5 \\ 2.0 & 1.5 & 1.8 & 1.7 \\ & 1.0 & 2.0 & 1.3\end{array}$

* The values in parentheses are the numbers of identifiable precipitates in the reference system.

\section{DISCUSSION}

The serological results indicate that 'Nocardia' mediterranea should be separated from Streptomyces and Streptoverticillium. This is not only in agreement with the numerical phenetic results of Alderson et al. (1981) and Williams et al. (1983), but also with chemotaxonomical (Thiemann et al., 1969; Kroppenstedt \& Kutzner, 1978; Alderson et al., 1981) and phage hostrange studies (Wellington \& Williams, 1981).

The two test strains of Streptoverticillium shared a limited number of antigens with the strains of Streptomyces. These two genera were not clearly distinguished serologically, indicating a comparatively close relationship. Although they can be distinguished phenetically (Williams et al., 1983), they share a cell wall chemotype I (Lechevalier \& Lechevalier, 1970) and can be infected by the same phages (Wellington \& Williams, 1981). 
A large number of described Streptomyces and Streptoverticillium species have been distributed at the $77.5 \% S_{S M}$ similarity level into 19 major, 40 minor and 18 single-membered clusters by numerical phenetic analysis (Williams et al., 1983). The major clusters can be regarded as species or species groups; representatives of nine of these clusters were included in the present study. Although serological cross-reactions occurred between all the streptomycete test and reference strains, the largest numbers of precipitinogens were formed between strains from the same cluster. There was also an overall tendency for the number of precipitinogens to match the similarity levels (Table 2). This relationship was not absolute but, in general, strains with a phenetic similarity of $75 \%$ or more shared three or more precipitinogens.

Both the phenetic and serological results indicated that the four strains from cluster 1B $(S$. griseus, $S$. griseinus, $S$. griseobrunneus and $S$. globisporus) are very closely related and represent a single species. A similar conclusion can be drawn for the two strains of cluster 61 (S. goshikiensis and S. lavendulae) and cluster 55 (Stv. cinnamoneum and Stv. griseocarneum).

The results of this limited serological study support those of the phenetic classification (Williams et al., 1983), providing further evidence for the over-classification of Streptomyces species. They also indicate that serology has potential for the identification and classification of streptomycetes, thus supporting the conclusions of Cross \& Spooner (1963).

M.R. is grateful for support from the Ellen, Walter and Lennart Hesselman Foundation (Sweden). S. T.W. is grateful for support from The Science and Engineering Research Council (Great Britain). The skilful technical assistance of Vivianne Sundaeus and Gun Wallerström is gratefully acknowledged.

\section{REFERENCES}

Alderson, G., Goodfellow, M., Wellington, E. M., Williams, S. T., Minnikin, S. M. \& Minnikin, D. E. (1981). Chemical and numerical taxonomy of Nocardia mediterranea. Zentralblatt für Bakteriologie, Mikrobiologie und Hygiene (I Abteilung) Suppl. 11, 39-46.

Arden Jones, M. P., McCarthy, A. J. \& Cross, T. (1979). Taxonomic and serological studies on Micropolyspora faeni and Micropolyspora strains from soil bearing the specific epithet rectivirgula. Journal of General Microbiology 115, 343-354.

Baker, D., Pengelly, W. L. \& Torrey, J. G. (1981). Immunochemical analysis of relationships among isolated Frankiae (Actinomycetales). International Journal of Systematic Bacteriology 31, 148-151.

BAKER, R., Ridell, M., LIND, A.\& OUCHTERLONY, Ö. (1979). Immunodiffusion studies of various structural preparations from mycobacterial cells. International Archives of Allergy and Applied Immunology 59, 328-336.

Bowden, G. H., Hardie, J. M. \& Fillery, E. D. (1976). Antigens from Actinomyces species and their value in identification. Journal of Dental Research 55 Special Issue A, 192-204.

Bowman, T. \& Weinhold, A. R. (1963). Serological relationship of the potato scab organism and other species of Streptomyces. Nature, London 200, 599600.

Cross, T. \& SPOONER, D. F. (1963). The serological identification of streptomycetes by agar gel diffusion techniques. Journal of General Microbiology 33, 275282.

EDEBO, L. (1960). A new press for the disruption of bacterial cells and other micro-organisms. Journal of Biochemical and Microbiological Technology 2, 453479.

Holmberg, K. H., Nord, C. E. \& Wadström, T.
(1975). Serological studies of Actinomyces israelii by crossed immunoelectrophoresis: taxonomic and diagnostic considerations. Infection and Immunity 12, 398-403.

KROPPENSTEDT, R. M. \& KuTZNER, H. J. (1978). Biochemical taxonomy of some problem actinomycetes. Zentralblatt für Bakteriologie, Parasitenkunde, Infektionskrankheiten und Hygiene (I Abteilung) Suppl. 6, 125-133.

KWAPINSKI, J. B. G. (1970). Serological taxonomy and relationships of Actinomycetales. In The Actinomycetales pp. 345-369. Edited by H. Prauser. Jena: Gustav Fischer Verlag.

KWAPINSKI, J. B. G. (1972). The immunology of streptomycetes in terms of the cytoplasmic antigens. Canadian Journal of Microbiology 18, 1213-1219.

LaCEy, J., Goodfellow, M. \& Alderson, G. (1978). The genus Actinomadura Lechevalier and Lechevalier. Zentralblatt für Bakteriologie, Parasitenkunde, Infektionskrankheiten und Hygiene (I Abteilung) Suppl. 6, 107-117.

Lechevalier, M. P. \& LechevalieR, H. (1970). Chemical composition as a criterion in the classifiction of aerobic actinomycetes. International Journal of Systematic Bacteriology 20, 435-443.

OUCHTERLONY, Ö. (1958). Diffusion-in-gel methods for immunological analysis. I. Progress in Allergy 5, 178.

OUCHTERLONY, Ö. (1962). Diffusion-in-gel methods for immunological analysis. H. Progress in Allergy 6, 30154.

RIDELL, M. (1974). Serological study of nocardia and mycobacteria by using 'Mycobacterium' pellegrino and Nocardia corallina precipitation reference systems. International Journal of Systematic Bacteriology 24, 64-72.

RIDELL, M. (1975). A taxonomic study of Nocardia 
farcinica using serological and physiological characters. International Journal of Systematic Bacteriology 25, 124-132.

RIDELL, M. (1981a). Immunodiffusion studies of Mycobacterium, Nocardia and Rhodococcus for taxonomic purposes. Zentralblatt für Bakteriologie, Mikrobiologie und Hygiene (I Abteilung) Suppl. 11, 235242.

RIDELL, M. (1981 b). Immunodiffusion studies of some Nocardia strains. Journal of General Microbiology 123, 69-74.

RIDELL, M. (1983). Immunodiffusion analyses of Mycobacterium farcinogenes, Mycobacterium senegalense and some other mycobacteria. Journal of General Microbiology 129, 613-619.

RIDELL, M. \& NorLIN, M. (1973). Serological study of Nocardia by using mycobacterial precipitation reference systems. Journal of Bacteriology 113, 1-7.

Thiemann, J. E., Zucco, G. \& Pelizza, G. (1969). A proposal for the transfer of Streptomyces mediterranei Margalith and Beretta 1960 to the genus Nocardia as
Nocardia mediterranea (Margalith and Beretta) comb. nov. Archiv für Mikrobiologie 67, 147-155.

VRUGGinK, H. \& MatT, D. Z. (1968). Serological recognition of Streptomyces species causing scab on potato tubers. Netherlands Journal of Plant Pathology 74, 35-43.

WADSWORTH, C. (1962). A microplate technique employing a gel chamber compared with other micro- and macroplate techniques for immune diffusion. International Archives of Allergy and Applied Immunology 21, 131-137.

Wellington, E. M. H. \& Williams, S. T. (1981). Host ranges of phages isolated to Streptomyces and other genera. Zentralblatt für Bakteriologie Mikrobiologie und Hygiene (I Abteilung) Suppl. 11, 93-98.

Williams, S. T., Goodfellow, M., Alderson, G., Wellington, E. M. H., Sneath, P. H. A. \& Sackin, M. J. (1983). Numerical classification of Streptomyces and related genera. Journal of General Microbiology 129, 1743-1813. 